\title{
The Predictive Value of Neutrophil-Lymphocyte Ratio in Disability of Gullain-Barrè Syndrome
}

\section{Gullain-Barrè Sendromu'ndaki Özürlülükte Nötrofil-Lenfosit Oranının Prediktif Değeri}

\author{
(D) Şadiye Gümüşyayla, (D) Gönül Vural \\ Ankara Yıldırım Beyazıt University Faculty of Medicine, Department of Neurology, Ankara, Turkey
}

\section{ABSTRACT}

Objective: Neutrophil-lymphocyte ratio (NLR) has become a method used to determine the adverse outcome of many medical conditions. In this study, it was investigated that whether NLR could be used in predicting disability in Gullain-Barrè seyndrome (GBS) patients.

Methods: Fifty GBS patients and 49 healthy volunteers were included in the study. NLR was calculated from neutrophil and lymphocyte counts in complete blood counts from all participants. The Hughes and Medical Research Council (MRC) sum scale were calculated at the time of admission and 3 months after the application from file records of all GBS patients. Whether or not there was a difference in NLR ratio between the patient and the healthy individuals and the relationship between NLR and disability scores were examined.

Results: White blood cell, neutrophil and monocyte count and NLR were found to be significantly higher in GBS patients participating in the study than healthy volunteers. In addition, NLR was positively correlated with the Hughes score and negatively correlated with the MRC sum score calculated at the time of admission and three months after admission.

Conclusion: This is the first study to examine the relationship between NLR and disability in GBS patients. In GBS patients, NLR can be employed as an easily accessible and inexpensive method for predicting disability.

Keywords: Gullain-Barré syndrome, neutrophil-lymphocyte ratio, disability

ÖZ

Amaç: Nötrofil-lenfosit oranı (NLR) pek çok medikal durumun sonuçlarını belirlemede kullanılan bir yöntem haline gelmiștir. Bu çalıșmada Gullain-Barrè sendrom'lu (GBS) hastalarında özürlülüğü önceden belirlemede NLR'nin kullanılıp kullanılamayacağını araștırılmışıır.

Yöntemler: Çalıșmaya 50 GBS hastası ve 49 sağıkı gönüllü dahil edildi. Tüm katılımcılardan alınan tam kan sayımında nötrofil ve lenfosit sayılarından NLR hesap edildi. Tüm GBS hastalarının dosya kayıtlarından bașvuru sırasında ve bașvurudan 3 ay sonra Hughes ve Tıbbi Araştırma Komisyonu (MRC) toplam skoru hesaplandı. Hasta ve sağlıkılar arasında NLR oranı açısından fark olup olmadığı ve NLR ile özürlülük skorları arasındaki ilişki incelendi.

Bulgular: Çalıșmaya katılan GBS hastalarında toplam beyaz küre, nötrofil ve monosit sayısı ile NLR sağlıklı gönülüllere göre anlamlı olarakyüksek bulundu. Ayrıca NLR başvuru sırasında ve bașvurudan üç ay sonra hesaplanan Hughes skoru ile pozitif, MRC toplam skoru ile ise negatif olarak korale bulundu.

Sonuç: Bu çalıșma GBS hastalarında NLR ile özürlülük arasındaki ilișkiyi inceleyen ilk çalışmadır. GBS hastalarında NLR özürlülüğü predikte etmede kolay ulaşılan ve ucuz bir yöntem olarak kullanılabilir.

Anahtar Kelimeler: Gullain-Barre sendromu, nötrofil-lenfosit oranı, disabilite

Received/Geliș tarihi: 14.12.2017 | Accepted/Kabul tarihi: 12.06 .2019

Address for Correspondence/Yazıșma Adresi: Şadiye Gümüşyayla, Ankara Yıldııım Beyazıt University Faculty of Medicine, Department of Neurology, Ankara, Turkey

E-mail/E-posta: sadiyetemel@yahoo.com ORCID-ID: orcid.org/0000-0002-2279-2016

Citation/Atıf: Gümüșyayla Ș, Vural G. The Predictive Value of Neutrophil-Lymphocyte Ratio in Disability of Gullain-Barre Syndrome. Bakırköy Tıp Dergisi 2019;15:187-92 https://doi. org/10.4274/BTDMJB.galenos.2019. 20171214071335 


\section{INTRODUCTION}

Guillain-Barrè syndrome (GBS) is a heterogeneous group of clinical and pathologic entity caused by the autoimmune system. An antecedal infection is thought to trigger an immunological reaction and form a disease by causing axonal degeneration and demyelination with a crossreaction. Even the first autopsy reports show that water retantion found in peripheral nerves with intermittent inflammatory infiltrates in the disease (1). With perivascular lymphocyte and macrophages infiltration, inflammation is thought to lead to demyelination (1-3). In particular, it is considered that $\mathrm{T}$ cell-mediated immunity plays a key role in the development of the disease, which is supported by experimental models of the disease. The disease results in complete recovery of approximately $70 \%$ of the patients, while in some cases it may result in morbidity in the character of weakness and mortality in very few cases (46).

Immune response to various physiological changes in the organism occurs as an increase in the number of neutrophils and a decrease in the number of lymphocytes (7-9). It can also be used as an immunological marker in predicting the adverse outcome of disease states such as cancer and cardiovascular diseases (7,10-13). Thus, the neutrophil-lymphocyte ratio (NLR) seen on the venous blood is an easily accessible and cheap marker of subclinical inflammation (14). NLR has been demonstrated to be more effective than white blood cell (WBC) count in determining adverse outcome in various diseases (10-13). NLR may be a marker of the organism's inflammatory status as it coevaluates neutrophil that exhibit end-of-inflammation and lymphocytes that exhibit regulatory mechanisms (14-16).

Early detection of prognosis in GBS is significant for true management of the disease and for early and effective treatment. Till now, the NLR ratio has never been studied in predicting prognosis in GBS. We aimed to investigate whether this laboratory parameter predicts the prognosis in the disease by studying the ratio of NLR in GBS.

\section{METHOD}

Between January 2012 and July 2016, 50 GBS patients who met the specified inclusion criteria and were treated in the neurology clinic or in the neurology intensive care unit of the Ankara Atatürk Training and Research Hospital and 49 healthy volunteers who did not have known neurological and systemic disease were included in this study. GBS diagnosis was based on international GBS diagnostic criteria. All demographic and clinical information of the patient was obtained by retrospectively reviewing the patient files. Other GBS patients with known systemic and neurological disease were excluded from the study. Blood was taken from the patients within 12 hours of admission to the hospital for a complete blood count. Complete blood counts were studied in all patients and healthy volunteers. Those with acute infection were excluded from the study. Blood samples were evaluated for total WBC count, neutrophil count, lymphocyte count and monocyte count, and the NLR ratio was calculated from these parameters. Informations about demographic data, neurological examinations, and treatments were obtained from patient files. Disability scores such as the Hughes scale and the medical research council (MRC) sum scale were calculated from the neurological examination datas obtained from the patient's files. For each patient, the Hughes scale and the MRC sum scale were recalculated 3 months after the treatment from the neurological examinations done at the outpatient clinic visits 3 months after the admission date.

The Hughes Functional Grading Scale Score: It was first used by Hughes to assess the efficacy of prednisolone therapy in GBS cases, and then it has been shown to be valid between observers by Kleyweg et al. $(17,18)$. The cases are classified in the following fashion below and show a negative result as the score goes up, a positive result when the score goes down.

0- Normal,

1- There are mild symptoms and signs but no functional limitation,

2- Can walk without assistance more than $10 \mathrm{~m}$,

3- Can walk more than $10 \mathrm{~m}$ with support or walker,

4- Dependent on bed or wheelchair,

5- At least a part of the day requires ventilator support, 6- Death.

MRC Sum Scale: A scoring of the upper and lower extremities obtained by summing the MRC scale separately on 6 muscles on both sides. The score ranges from 0 (total paralysis) to 60 (normal strength) (19).

\section{Statistical Analysis}

Gender of the individuals involved in the study, and number and percentage values of the treatment methods of the sick 
individuals were given. The suitability to normal distribution of continuous variables was evaluated by the ShapiroWilks test. The median and interquartile range (IQR) was used to represent the descriptive statistics of the variable that was not normally distributed. Gender comparisons between patients and control groups were analyzed by chisquare comparison test. Assuming that the age variable is normally distributed, the independent 2 sample $T$ test was used to analyze whether there was a significant difference between the patient and control groups. The values of the WBC, neutrophil, monocyte, lymphocyte, and NLR ratio were analyzed by the Mann-Whitney $U$ test to see whether there was a statistical difference in these values in the patient and control groups. A correlation analysis was performed between variables of the NLR ratio and the Hughes scale and MRC sum scale of the individuals in the patient group and Spearman's Rho Correlation Coefficients calculated. For statistical analysis and calculations, IBM SPSS Statistics 21.0 (IBM Corp. released 2012. IBM SPSS Statistics for Windows, version 21.0, Armonk, NY) and MS Excel 2007 programs were used for some calculations. Statistical significance level was accepted as $p<0.05$.

\section{RESULTS}

The mean age of the individuals in the patient group was calculated as $52.80 \pm 17.01$ and the mean age of the individuals in the healthy control group was calculated as $52.53 \pm 17.15$. There was no statistically significant difference in terms of age and gender in the patient and control groups ( $p$ values, respectively: 0.938, 0927). Forty-five of the patients in the patient group received intravenous immunoglobulin (IVIg) therapy, 2 received plasmapheresis, and finally 3 received $\mathrm{IVIg}+$ plasmapheresis treatments. While $14 \%(n=7)$ of patients were receiving respiratory support, $86.0 \% \quad(n=43)$ were not receiving respiratory support.

In the study, the median of WBC in the patient group was calculated as $9.46(I Q R=3.10)$ and the median of WBC in the control group was calculated as 7.32 (IQR=2.77). The WBC values of the individuals in the patient group were found to be higher than the values of the individuals in the control group. WBC values of patients and control groups showed statistically significant difference $(p<0.001)$. Median of the neutrophil values of the individuals in the patient group was $6.33(\mathrm{IQR}=2.78)$ and $4.47(\mathrm{IQR}=1.91)$ in the control group, respectively. There was statistically significant difference in neutrophil values between patient and control groups $(p<0.001)$. The neutrophil values of the individuals in the patient group are higher than those in the control group. The lymphocyte median of the GBS patients in the study was $2.02(\mathrm{IQR}=1.23)$ and median of lymphocyte values in the healthy control group was 2.16 $(\mathrm{IQR}=0.85)$. Lymphocyte levels did not differ statistically significant between patients and control groups ( $p=0.588$ ). Median of the monocyte values of the individuals in the patient group was calculated as $0.65(\mathrm{IQR}=0.39)$ and 0.54 $(\mathrm{IQR}=0.28)$ in the control group, respectively. The monocyte values of patients and control groups showed statistically significant difference $(p=0.033)$. The monocyte values of the individuals in the patient group were higher than those in the control group. Median of the NLR ratio of individuals in the study who were in the GBS patient group was calculated as 2.99 (IQR=2.88) and 2.17 (IQR=1.13) in the control group, respectively. The NLR ratios between patients and control groups demonstrated statistically significant difference $(p<0.001)$. Individuals in the patient group have higher NLR ratios than the control group (Table 1).

A moderate, linear, positive, and statistically significant relationship was found between the NLR ratios of the individuals involved in the study and the Hughes scale at the time of admission and the Hughes scale at the third month ( $p=0.001, p=0.010$, respectively). A negative, linear, weak and statistically significant relationship was found between the NLR ratios of the individuals and the MRC sum scale at the time of admission and the MRC sum scale at the third month ( $p=0.005, p=0.020$, respectively) (Table 2 ).

Table 1: Descriptive statistics of the variables in the patient and control groups

\begin{tabular}{lllll}
\hline Variables & \multicolumn{4}{c}{ Group } \\
& $\begin{array}{l}\text { Median of } \\
\text { patients (IQR) }\end{array}$ & $\begin{array}{l}\text { Median of } \\
\text { controls } \\
\text { (IQR) }\end{array}$ & z & p \\
\hline WBC & $9.46(3.10)$ & $7.32(2.77)$ & 3.958 & $<\mathbf{0 . 0 0 1}$ \\
Neutrophil & $6.33(2.78)$ & $4.47(1.91)$ & 4.850 & $\mathbf{< 0 . 0 0 1}$ \\
Monocyte & $0.65(0.39)$ & $0.54(0.28)$ & 2.128 & $\mathbf{0 . 0 3 3}$ \\
Lemphocyte & $2.02(1.23)$ & $2.16(0.85)$ & 0.542 & 0.588 \\
NLR & $2.99(2.88)$ & $2.17(1.13)$ & 3.765 & $<\mathbf{0 . 0 0 1}$ \\
\hline
\end{tabular}

Mann-Whitney U non parametric test, IQR: Interquartile range, WBC: White blood cell, NLR: Neutrophil-lymphocyte ratio 
Table 2: Corelation analysis of variables

\begin{tabular}{lll}
\hline Variables & Spearman rho & $\mathbf{p}$ \\
\hline NLR-Hughes scores at admission & 0.461 & $\mathbf{0 . 0 0 1}$ \\
NLR-Hughes scores at third month & 0.360 & $\mathbf{0 . 0 1 0}$ \\
NLR-MRC sum scores at admission & -0.395 & $\mathbf{0 . 0 0 5}$ \\
NLR-MRC sum scores at third month & -0.327 & $\mathbf{0 . 0 2 0}$ \\
\hline NLR: Neutrophil-lymphocyte ratio, MRC: Medical research council & \\
\hline
\end{tabular}

\section{DISCUSSION}

In this study, we found that the WBC, neutrophil and monocyte counts and NLR ratio in the complete blood count during admission in GBS diagnosed patients were higher than in healthy volunteers. However, the number of lymphocytes was not different compared to the healthy individuals. We also found a positive correlation between the NLR ratio and the Hughes scale at the time of referral and three months after the referral; however, the NLR ratio to be negatively correlated with MRC sum scale at the time of referral and three months after the referral. Thus, we thought that the NLR ratio calculated during the application could predict the disability status of GBS patients 3 months later at the time of the admission.

GBS is an inflammatory demyelinating disease of the peripheral nervous system. It is caused by an aberrant immune response that develops directly against some components of the peripheral nerves. Though there is a T-cell mediated response predominantly to some myelin proteins, a complex inflammatory pathogenesis is involved, in which both humoral and cellular immunity are influenced (20). Molecular mimicry and cross reactivity triggered by some infectious agents, especially Campylobacter jejuni, initiates the events in the immunological system (21). Clinical worsening followed by plateauing phase and possibly healing period during the course of the illness suggests inflammatory phase first and then regulation of inflammation in the disease.

In our study, WBC, neutrophil and monocyte counts were significantly higher in GBS patients than healthy volunteers. In some studies, monocyte counts in GBS patients were not found different from healthy volunteers $(22,23)$. Furthermore, in our study, GBS patients had higher numbers of WBC and neutrophils than healthy volunteers. We could not find any information on this topic when we searched the literature. However, in cases of post infectious monophasic diseases such as reactive arthritis and rheumatoid fever, where the immunopathogenesis is similar to GBS patients, the high number of WBC and neutrophils are diagnostic laboratory parameters. It is also a trigger for infections in the pathogenesis of GBS, which may lead to an increase in some acute phase markers that may raise the number of WBC, neutrophils and monocytes in the acute state as a consequence of the acute phase reaction in this patient group $(20,24)$. We found that lymphocyte counts in GBS patients were lower than healthy individuals, but this difference was not significant. The results of studies on numbers of lymphocytes in the acute phase in GBS patients showed differences. Some studies did not find lymphocyte counts compatible with our study, whereas in some studies, the number of $\mathrm{T}$ lymphocytes decreased and the number of B lymphocytes increased (25-27). This might be owing to differences in types of lymphocytes and different roles of different types of lymphocytes in the immune system and for this, it is necessary to examine the lymphocyte numbers typed by the flow cytometry method. Different results have been obtained related to this subject as well $(22,25,26,28,29)$.

The NLR is a dynamic parameter that the predictive value of this parameter is superior to the total leukocyte count. This equilibrium constituted by both neutrophilia and lymphocyte counts that indicates the inflammation on the one hand and the regulation of inflammation on the other due to its components. Neutrophils show active non-specific inflammation and are one of the body's first defense mechanisms. Lymphocytes are the regulatory and protective component of inflammation. NLR has previously been studied in diseases such as diabetes mellitus, coronary artery disease and intracerebral haemorrhage (7,11-15). We have studied this parameter first time in GBS patients. We think that NLR can be affected in this disease and related to the disability of the disease, starting from the idea that contains inflammation and resolution of inflammation in GBS. We found the NLR ratio in GBS patients to be higher than in healthy volunteers. Moreover, the NLR ratio was positively correlated with the Hughes Scale and negatively correlated with the MRC sum scale at the time of admission and three months after admission. This showed that the NLR ratio could be used for predicting the disability in the disease. Pritchard et al. (22) found that circulating CD4 + CD25 + populations in GBS patients decreased and this was attributed to impaired regulatory function of the immune system. NLR is an important parameter as it provides information easily accessible, easily calculated and inexpensive about systemic inflammation, and could be a 
parameter that can be employed for predicting the adverse outcome of systemic inflammation-induced diseases (14).

\section{Study Limitations}

This study has some limitations; i) This study was retrospectively designed and was relatively small in the number of samples, ii) The disease consists of a heterogeneous group of entity and the disease subgroups have not been individually studied, iii) This study has not been designed to elicit the mechanistic pathways leading to an increase in the NLR ratio in GBS patients.

\section{CONCLUSION}

In summary, the NLR ratio is strongly correlated with disability in GBS. This parameter is very inexpensive and very easily accessible parameter. There is still a need for large cohort studies that analyze lymphocytes in their subtypes and take into account changes in different subgroups of the disease.

\section{Ethics}

Ethics Committee Approval: Our study is a retrospective study.

Informed Consent: Our study is a retrospective study.

Peer-Review: Exterally peer-reviewed.

\section{Authorship Contributions}

Concept: Ș.G., G.V., Design: Ș.G., G.V., Data Collection or Processing: S..G., G.V., Analysis or Interpretation: S..G., G.V., Literature Search: S..G., G.V., Writing: S..G., G.V.

Conflict of Interest: No conflict of interest was declared by the authors.

Financial Disclosure: The authors declared that this study received no financial support.

\section{REFERENCES}

1. Winer JB. An update in guillain-barré syndrome. Autoimmune Dis 2014;2014:793024.

2. Asbury AK, Arnason BG, Adams RD. The inflammatory lesion in idiopathic polyneuritis. Its role in pathogenesis. Medicine (Baltimore) 1969;48:173-215.

3. Prineas JW. Acute idiopathic polyneuritis. An electron microscope study. Lab Invest. 1972;26:133-47.

4. Linington C, Izumo S, Suzuki M, Uyemura K, Meyermann R, Wekerle $\mathrm{H}$. A permanent rat $\mathrm{T}$ cell line that mediates experimental allergic neuritis in the Lewis rat in vivo. J Immunol 1984;133:1946-50.
5. Izumo S, Linington C, Wekerle $\mathrm{H}$, Meyermann R. Morphologic study on experimental allergic neuritis mediated by $T$ cell line specific for bovine P2 protein in Lewis rats. Lab Invest 1985;53:209-18.

6. Hughes RA, Cornblath DR. Guillain-Barré syndrome. Lancet 2005;5:1653-66.

7. Shiny A, Bibin YS, Shanthirani CS, Regin BS, Anjana RM, Balasubramanyam $M$, et al. Association of neutrophil-lymphocyte ratio with glucose intolerance: an indicator of systemic inflammation in patients with type 2 diabetes. Diabetes Technol Ther 2014;16:524-30.

8. Mansoori D, Jamaati HR, Arami S, Zadsar M, Abbasian L, Esteghamati AR. Comparison of lymphocyte number and their subsets in patients with diabetes mellitus type II, tuberculosis and concomitant TB and diabetes. Tanaffos 2002;1:45-50.

9. Von Vietinghoff $S$, Ley K. Homeostatic regulation of blood neutrophil counts. J Immunol 2008;181:5183-8.

10. Duncan BB, Schmidt MI, Pankow JS, Ballantyne CM, Couper D, Vigo A et al. Low-grade systemic inflammation and the development of type 2 diabetes: the atherosclerosis risk in communities study. Diabetes 2003;52:1799-1805.

11. Imtiaz F, Shafique K, Mirza S, Ayoob Z, Vart P, Rao S. Neutrophil lymphocyte ratio as a measure of systemic inflammation in prevalent chronic diseases in Asian population. Int Arch Med 2012;5:2.

12. Ishizuka M, Nagata $H$, Takagi K, Iwasaki Y, Kubota K. Combination of platelet count and neutrophil to lymphocyte ratio is a useful predictor of postoperative survival in patients with colorectal cancer. $\mathrm{Br} \mathrm{J}$ Cancer 2013;109:401-7.

13. Sen N, Afsar B, Ozcan F, Buyukkaya E, Isleyen A, Akcay AB, et al. The neutrophil to lymphocyte ratio was associated with impaired myocardial perfusion and long term adverse outcome in patients with ST-elevated myocardial infarction undergoing primary coronary intervention. Atherosclerosis 2013;228:203-10

14. Celikbilek M, Dogan S, Ozbakır O, Zararsız G, Kücük H, Gürsoy S et al. Neutrophil-lymphocyte ratio as a predictor of disease severity in ulcerative colitis. J Clin Lab Anal 2013;27:72-6.

15. Avanzas P, Quiles J, López de Sá E, Sánchez A, Rubio R, García E et al. Neutrophil count and infarct size in patients with acute myocardial infarction. Int J Cardiol 2004;97:155-6.

16. Ommen SR, Hodge DO, Rodeheffer RJ, McGregor CG, Thomson SP, Gibbons RJ. Predictive power of the relative lymphocyte concentration in patients with advanced heart failure. Circulation 1998;97:19-22.

17. Hughes RA, Newsom-Davis JM, Perkin GD, Pierce JM. Controlled trial prednisolone in acute polyneuropathy. Lancet 1978;312:750-3.

18. Kleyweg RP, van der Meche FG, Schmitz PI. Interobserver agreement in the assessment of muscle strength and functional abilities in Guillain-Barre syndrome. Muscle Nerve 1991;14:1103-9.

19. van KR, Steyerberg EW, Hughes RA, Swan AV, van Doorn PA, Jacobs $B C$. A clinical prognostic scoring system for Guillain-Barre syndrome. Lancet Neurol 2007;6:589-94.

20. Hartung HP, Pollard JD, Harvey GK, Toyka KV. Immunopathogenesis and treatment of the Guillain-Barré syndrome--Part I. Muscle Nerve 1995;18:137-53.

21. van Doorn PA, Ruts $L$, Jacobs BC. Clinical features, pathogenesis, and treatment of Guillain-Barré syndrome. Lancet Neurol 2008;7:939-50.

22. Pritchard J, Makowska A, Gregson NA, Hayday AC, Hughes RA. Reduced circulating CD4+CD25+ cell populations in Guillain-Barré syndrome. J Neuroimmunol 2007;183:232-8.

23. Borsellino Gl, Poccia F, Placido R, Tramonti D, Mancino G, Luchetti $S$ et al. Phenotypic and functional properties of gamma delta $T$ 
cells from patients with Guillain Barré syndrome. J Neuroimmunol 2000;102:199-207.

24. Harvey GK, Pollard JD. Peripheral nervous system demyelination from systemic transfer of experimental allergic neuritis serum. J Neuroimmunol 1992;41:159-66.

25. Dahle C, Vrethem M, Ernerudh J. T lymphocyte subset abnormalities in peripheral blood from patients with the Guillain-Barré syndrome. J Neuroimmunol 1994;53:219-25.

26. Sindern E, Oreja-Guevara C, Raulf-Heimsoth M, Baur X, Malin J.P. A longitudinal study of circulating lymphocyte subsets in the peripheral blood during the acute stage of Guillain-Barré syndrome. J Neurol Sci 1997;151:29-34.
27. Yoshii F, Shinohara Y. Lymphocyte subset proportions in GuillainBarré syndrome patients treated with plasmapharesis. Eur Neurol 2000;44:162-7.

28. Hou HQ, Miao J, Feng XD, Han M, Song XJ, Guo L. Changes in lymphocyte subsets in patients with Guillain-Barre syndrome treated with immunglobulin. BMC Neurol 2014;15:202.

29. Guo L, Hou HQ, Song XJ, Yang JC, Gao CY. Change of T-Lymphocyte subsets in the patients with Gullain-Barre syndrome between pre and post-therapy with intravenous immunoglobulin and its meaning. Chin J Neurol 2008;41:87-90. 